\title{
BIMBINGAN DAN KONSELING BAGI SISWA DI ERA DISRUPSI
}

\author{
Nilda Miftahul Janna : 18210047 \\ Dosen Pembimbing : Ibnu Hajar Sainuddin \\ Sekolah Tinggi Agama Islam (STAI) Darul Dakwah Wal-Irsyad (DDI) Kota Makassar, Indonesia \\ Email: nildamiftahuljanna@gmail.com
}

\begin{abstract}
ABSTRAK
Perubahan peradaban manusia terjadi sejak dahulu dari peradaban masyarakat primitif, ke masyarakat agraria, dan selanjutnya ke peradaban masyarakat revolusi industri. Revolusi industri ada empat tahap yakni industri 1.0, 2.0, 3.0, hingga industri 4.0. Revolusi industri 4.0 telah mendorong inovasi-inovasi teknologi yang memberikan dampak disrupsi atau perubahan fundamental terhadap kehidupan masyarakat. Perubahan dampak disrupsi merambah semua aspek kehidupan termasuk dalam bidang pendidikan, serta bimbingan dan konseling. Bimbingan dan konseling di sekolah merupakan pelayanan secara luas dan efektif yang bertujuan untuk membantu peserta didik dalam mencapai tujuan perkembangannya dan juga mengatasi permasalahan siswa yang pastinya akan selalu muncul dalam setiap jenjang kehidupan. Era disrupsi adalah era dimana perubahan besar terjadi dalam kehidupan manusia. Perubahan tersebut terjadi lantaran terjadinya perubahan dan sumber energi yang berasal dari manusia menjadi serba mesin yang dijalankan secara otomatis lewat kekuatan yang bernama teknologi. Saat ini teknologi tidak dapat dilepaskan dari kehidupan manusia. Kemajuan teknologi menciptakan disrupsi pada kehidupan sehari-hari, mulai dari otomatisasi yang mengancam ragam mata pencaharian, hingga bagaimana masyarakat mencerna dan juga mengabarkan informasi. Dan dalam aratikel ini kita akan membahas tentang bimbingan dan koseling bagi siswa di era disrupsi.
\end{abstract}

\section{Kata Kunci : Bimbingan, Konseling, Siswa, Era, Disrupsi}

\section{A. PENDAHULUAN}

Perubahan peradaban manusia terjadi sejak dahulu dari peradaban masyarakat primitif, ke masyarakat agraria, dan selanjutnya ke peradaban masyarakat revolusi industri. Schwab, Ekonom terkenal asal Jerman, Pendiri dan Ketua Eksekutif World Economic Forum (WEF) mengenalkan konsep Revolusi Industri 4.0. Dalam bukunya yang berjudul "The Fourth Industrial Revolution". (Rosyadi, 2018: 1) menjelaskan adanya empat tahap revolusi industri, yakni industri 1.0, 2.0, 3.0, hingga industri 4.0. Revolusi industri 4.0 telah mendorong inovasi-inovasi teknologi yang memberikan dampak disrupsi atau perubahan fundamental terhadap kehidupan masyarakat. Satu disrupsi akibat teknologi adalah pasar kerja (Stillman, 2018: 51). ${ }^{1}$

Perubahan dampak disrupsi merambah semua aspek kehidupan termasuk dalam bidang pendidikan, serta bimbingan dan konseling. Presiden RI Joko Widodo (dalam Suwardana, 2017: 105) menyampaikan gagasan betapa pentingnya dilakukan revolusi mental, karena

${ }^{1}$ Retnaningdyastuti, M. T. S. R. (2018). Tantangan dan peluang siswa dan guru BK di era disrupsi. Prosiding, hlm. 6. 
perubahan harus ke arah lebih baik bukan hanya pada institusi tapi juga perubahan pada manusianya. Perubahan merupakan keniscayaan. Namun faktanya perkembangan peradaban di Indonesia tidak linear, tetapi lebih berlangsung secara paralel. Pada masa sekarang peradaban masyarakat di Indonesia ada yang menunjukkan masih primitif, ada yang agraris, ada yang industri 1.0, 2.0, 3.0, dan 4.0. Salah satu penyebabnya adalah adanya masyarakat yang belum terjangkau internet, bahkan masih berupa wilayah blank spot. Oleh karena itu berimplikasi terhadap perkembangan pelayanan pendidikan serta bimbingan dan konseling. Kondisi ini akan berimplikasi terhadap peluang dan tantangan bagi siswa dan guru BK di era disrupsi. $^{2}$

Bimbingan dan konseling di sekolah merupakan pelayanan secara luas dan efektif yang bertujuan untuk membantu peserta didik dalam mencapai tujuan-tujuan perkembangannya dan juga mengatasi permasalahan peserta didik yang pastinya akan selalu muncul dalam setiap jenjang kehidupan. Layanan bimbingan dan konseling memiliki kedudukan yang sangat penting dalam setting pendidikan formal yang sejajar dengan layanan manajemen Pendidikan dan layanan pembelajaran. Dalam memenuhi pelayanan bimbingan dan konseling yang begitu sentral dalam Pendidikan maka dibutuhkan pula peran konselor yang memiliki kompetensi dan kualifikasi yang mumpuni dalam menyelenggarakan layanan bimbingan konseling baik kompetensi pedagogik, kompetensi sosial, kompetensi professional, maupun kompetensi kepribadian. Hal itu diperlukan agar pelayanan yang diberikan kepada peserta baik dapat berjalan dengan baik dan optimal. ${ }^{3}$

Era disrupsi adalah era dimana perubahan besar terjadi dalam kehidupan manusia. Perubahan tersebut terjadi lantaran terjadinya perubahan dan sumber energi yang berasal dari manusia menjadi serba mesin yang dijalankan secara otomatis lewat kekuatan yang bernama teknologi. Saat ini teknologi tidak dapat dilepaskan dari kehidupan manusia. Teknologi membantu setiap lini kehidupan. Teknologi menjadikan setiap kehidupan menjadi mudah. Perlu untuk betul-betul menggunakan teknologi kearah positif dan membangun. Salah satunya dalam kegiatan bimbingan dan konseling yang berbasis teknologi. Penggunaan teknologi dalam layanan bimbingan dan konseling mampu meningkatkan keterserapan materi yang diberikan dalam layanan bimbingan serta dapat mengefektifkan peran konselor sebagai fasilitator guna memandirikan peserta didik di sekolah. Konselor perlu untuk mengembangkan diri agar dapat mengaplikasikan teknologi kedalam layanan bimbingan dan konseling guna menciptakan layanan bimbingan dan konseling yang inovatif, kreatif, adaptif serta fleksibel di era disrupsi ini. ${ }^{4}$

Kemajuan teknologi menciptakan disrupsi pada kehidupan sehari-hari, mulai dari otomatisasi yang mengancam ragam mata pencaharian, hingga bagaimana masyarakat mencerna dan mengabarkan informasi. Dewasa ini, lebih dari setengah populasi di Indonesia sudah terhubung Internet. Angka penetrasi Internet makin tinggi dari tahun ke tahun. Eric

${ }^{2}$ Retnaningdyastuti, M. T. S. R. (2018). Tantangan dan peluang siswa dan guru BK di era disrupsi. Prosiding, hlm. 6.

${ }^{3}$ Nurpitasari, E., Aji, B. S., \& Kurniawan, S. J. (2018, November). Pengembangan Kompetensi Teknologi dan Peran Konselor dalam Menghadapi Peserta Didik di Era Disrupsi. In Seminar Nasional Bimbingan Konseling (Vol. 2, No. 1, pp. 10-14), hlm. 11.

${ }^{4}$ Kusumawati, E. (2020). PELUANG DAN TANTANGAN LAYANAN BIMBINGAN DAN KONSELING DI ERA DISRUPSI. Counsenesia Indonesian Journal Of Guidance and Counseling, 1(02), hlm. 64. 
Schmidt (2018) seorang insinyur dari Google, bahkan memprediksikan bahwa tahun 2020 nanti seluruh manusia didunia akan online. ${ }^{5}$

Generasi muda saat ini hidup di era perkembangan teknologi yang pesat. Hampir semua aktivitas yang dilakukan, terutama komunikasi, melekat dengan teknologi dan menjadi bagian dari kehidupan keseharian. Mereka telah akrab dengan teknologi digital sejak dini, dan bahkan cenderung memiliki ketergantungan terhadap teknologi. Mereka menghabiskan sebagian besar waktunya untuk menonton televisi, bermain video game secara onlie maupun offline, mendengarkan musik dari pemutar musik digital yang terkoneksi dengan internet, browsing dengan smartphone ataupun komputer, membina relasi sosial melalui media sosial, berbincang dengan orang atau kelompok dengan video call dan beragam peralatan digital lainnya. ${ }^{6}$

Perkembangan teknologi yang semakin pesat berdampak pada semua bidang termasuk bidang pendidikan. Beberapa tahun yang lalu semua hal yang dilakukan seseorang dalam kehidupannya dapat dilakukan sendiri (masih manual atau masih menggunakan potensi dalam diri seseorang tersebut), akan tetapi hal tersebut untuk saat ini berubah dan bertolak belakang dengan kondisi saat ini. Sebagai salah satu contohnya, beberapa tahun yang lalu sistem parkir masih menggunakan jasa manusia sebagai hal yang pokok, akan tetapi sekarang terdapat peralihan dalam hal tersebut yaitu dengan adanya e-parking. Sebagai contoh lainnya dalam bidang bimbingan dan konseling beberapa tahun yang lalu pemanfaatan layanan Bimbingan dan Konseling harus dilakukan face to face, akan tetapi semakin berkembangnya teknologi proses kegiatan layanan bimbngan dan konseling dapat dilakukan dengan memanfaatkan teknologi salah satunya dengan memanfaatkan konseling online atau cyber counselling. ${ }^{7}$

Sosial media menjadi salah satu kebutuhan masyarakat modern pada saat ini, akan tetapi bersosial media yang dilakukan secara terus menerus tanpa adanya batasan dapat mempengaruhi mental seeorang (Herianto, 2020). Oleh karena itu maka perlu diimbangi dengan kajian-kajian keagamaan untuk memfilter dan mengimbangi informasi pengetahuan yang di dapatkan. ${ }^{8}$

Untuk itu perlu dilakukan kajian tentang: era disrupsi, karakteristik siswa di era disrupsi, karakteristik guru di era disrupsi, tantangan dan peluang bagi siswa di era disrupsi, peranan teknologi dalam bimbingan dan konseling, dan kelebihan atau keuntungan penggunaan teknologi informasi dalam bimbingan dan konseling. Tujuan pembahasan ini adalah agar siswa dan guru BK (termasuk calon guru BK) menguasai wawasan tentang tantangan dan peluang bagi siswa dan guru BK di era disrupsi serta mempersiapkan siswa dan guru BK atau calon guru BK agar mampu mengelola tantangan menjadi peluang di era disrupsi yang bermanfaat untuk peningkatan mutu layanan pendidikan serta bimbingan dan konseling.

${ }^{5}$ Fatmawati, Nur Ika. "Literasi Digital, mendidik anak di era digital bagi orang tua milenial." Madani Jurnal Politik Dan Sosial Kemasyarakatan 11.2 (2019), hlm.120.

${ }^{6}$ Setiawan, Rizki. "Kebebasan Ekspresi Individual dalam Pembangunan Manusia Era Digital." Prosiding Seminar Nasional Pendidikan FKIP. Vol. 1. No. 2. 2017, hlm. 169.

${ }^{7}$ Kusumawati, E. (2020). PELUANG DAN TANTANGAN LAYANAN BIMBINGAN DAN KONSELING DI ERA DISRUPSI. Counsenesia Indonesian Journal Of Guidance and Counseling, 1(02), hlm. 5 .

'Sainuddin, Ibnu Hajar. "Dakwah di Era Sosial Media". 


\section{B. PEMBAHASAN \\ 1. Era Disrupsi}

Era disrupsi adalah istilah lain dari industri 4.0. Disebut era disrupsi karena otomatisasi dan konektivitas di sebuah bidang akan membuat pergerakan dunia menjadi tidak linier. Salah satu karakteristik unik dari industri 4.0 adalah pengaplikasian kecerdasan buatan atau artificial intelligence. Salah satu bentuk pengaplikasian tersebut adalah penggunaan robot untuk menggantikan tenaga manusia sehingga lebih murah, efektif, dan efisien. Tjandrawinata telah menjelaskan, kemajuan teknologi dengan adanya era disrupsi memungkinkan terjadinya otomatisasi hampir di semua bidang. Teknologi dan pendekatan baru yang menggabungkan dunia fisik, digital, dan biologi secara fundamental akan mengubah pola hidup dan interaksi manusia. Industri 4.0 sebagai fase revolusi teknologi mengubah cara beraktifitas manusia dalam skala, ruang lingkup, kompleksitas, dan juga transformasi dari pengalaman hidup sebelumnya. Manusia akan hidup dalam ketidakpastian (uncertainty) global. Oleh karena itu dengan demikian manusia harus memiliki kemampuan untuk memprediksi masa depan yang berubah begitu cepat termasuk didalamnya proses pembelajaran dalam dunia pendidikan. ${ }^{9}$

Menurut Christensen, C, (2015) disruption adalah menggantikan 'pasar lama', industri, dan teknologi, dan menghasilkan suatu kebaharuan yang lebih efisien dan menyeluruh. Ia bersifat destruktif dan kreatif. Destruktif, karena yang lama ketinggalan zaman, bahkan menimbulkan guncangan. Kreatif, karena di sisi lain inovasi kreatif menciptakan hal baru yang lebih efisien dan menyeluruh. Disrupsi (disruption) adalah inovasi menggantikan sistem lama dengan teknologi digital yang lebih efisien dan bermanfaat. Era disrupsi merupakan masa penuh gangguan karena banyak perubahan. Era disrupsi merupakan era yang ditandai perubahan yang fundamental dalam kehidupan di masyarakat sebagai dampak dari inovasi teknologi untuk merespon kebutuhan konsumen di masa yang akan datang. Era disrupsi teknologi dan revolusi digital adalah istilah lain dari revolusi industri 4.0. Fokus utama masyarakat industri adalah penguasaan ilmu pengetahuan dan teknologi untuk meningkatkan kualitas hidup. Pada era digital ini Indonesia memasuki era informasi dan komunikasi global. Dengan demikian era disrupsi adalah era revolusi industri 4.0 yang ditandai perubahan fundamental dalam kehidupan yang lebih efisien dan bermanfaat di masyarakat sebagai dampak dari inovasi teknologi digital melalui penguasaan dan pemanfaatan ilmu pengetahuan dan teknologi untuk meningkatkan kualitas hidup. ${ }^{10}$

Menurut Trillling dan Fadel (2009), pembelajaran abad 21 (era disrupsi) berorientasi pada gaya hidup digital, alat berpikir, penelitian pembelajaran dan cara kerja pengetahuan. Sehingga pada tahun 2020 struktur keterampilan siswa berubah menjadi: 1) pemecahan masalah yang kompleks; 2) berpikir kritis; 3) kreativitas; 4) manajemen orang; 5) kerjasama dengan orang lain 6) kecerdasan emosional; 7) penilaian dan pengambilan keputusan; 8) orientasi layanan; 9) negosiasi; dan 10) fleksibilitas kognitif (Irianto, 2017). Dari penjabaran diatas, dapat ditarik kesimpuan bahwa semua bentuk kecakapan dan keterampilan di era disrupsi yang dibutuhkan harus diintegrasikan ke dalam elemen pendidikan. Mulai dari sistem

${ }^{9}$ Tjandrawina, R.R. (2016). Industri 4.0: Revolusi industri abad ini dan pengaruhnya pada bidang kesehatan dan bioteknologi. Jurnal Medicinus, Vol 29 No 1, Edisi April.

${ }^{10}$ Retnaningdyastuti, M. T. S. R. (2018). Tantangan dan peluang siswa dan guru BK di era disrupsi. Prosiding, 6. Hlm.7 
pembelajaran, satuan pendidikan, peserta didik (siswa), hingga kepada pendidik dan tenaga kependidikan. $^{11}$

\section{Karakteristik Siswa di Era Disrupsi}

Menurut Mannheim (Wibawanto, 2018) generasi adalah kelompok yang terdiri dari individu yang memiliki kesamaan dalam rentang usia dan mengalami peristiwa sejarah penting dalam suatu periode waktu yang sama. Tapscott (2013: 18-39) dalam bukunya dengan judul "Grown Up Digital" membagi demografi penduduk Amerika kedalam beberapa kelompok generasi sebagai berikut :

- The Baby Boom (lahir antara 1946 - 1964)

- The Baby Bust atau Generasi X (lahir antara 1965 - 1976)

- The Millennial atau Generasi Y (lahir antara 1977 - 1997)

- Generation Net atau Generasi Z (lahir antara 1998 hingga kini). ${ }^{12}$

McCrindle (2016) menambahkan setelah generasi Y pada tahun 2010 lahir generasi Alpha. Menurut pendapat Marteney (Hasugian, 2011: 12) generasi Z adalah digital natives. Menurut pendapat Mardiana (2011: 7) generasi digital natives mengganggap perangkat komunikasi teknologi komputer sebagai bagian integral dari kehidupannya. Seorang individu yang lahir pada abad digital, tumbuh dan memperoleh pendidikan pada tingkat sekolah dasar dengan menggunakan perangkat komputer, seperti: kuiz interaktif online, video games, handphone, internet, e-mail. Oleh karena itu pembahasan ini difokuskan pada generasi Z. Menurut Susana (2012: 57) generasi Z disebut juga Generation Net dengan ciri-ciri sebagai berikut: (a) memiliki akses yang cepat terhadap informasi dari berbagai sumber, (b) dapat mengerjakan beberapa hal dalam waktu bersamaan (multitasking), (c) lebih menyukai hal-hal yang bernuansa atau bernapaskan multimedia, (d) lebih menyukai berinteraksi melalui dunia maya, jejaring sosial (Facebook, Twitter, Yahoo Messenger, hingga BBM), dan (e) dalam belajar, lebih menyukai hal-hal yang bersifat aplikatif dan menyenangkan. ${ }^{13}$

Djiwandono menyatakan bahwa generasi $\mathrm{Z}$ mempunyai kecenderungan gaya belajar aktif, global, sensing, dan visual. Pembelajar aktif mudah belajar dengan melakukan sendiri apa yang sedang dipelajari. Global berarti individu cenderung belajar dengan cara melompatlompat, menyerap materi secara random tanpa melihat keterkaitan antara yang satu dengan yang lain, dan tiba-tiba bisa mendapatkan sesuatu. Pembelajar global juga cenderung mampu mengatasi masalah yang kompleks secara cepat atau merangkai segala sesuatu dengan cara baru ketika mereka dapat meraba gambaran besarnya, tetapi mungkin sulit menjelaskan bagaimana prosesnya. Gaya belajar sensing cenderung menyukai fakta, menyukai hal-hal yang penerapan praktisnya jelas, mengharapkan relevansi dengan dunia sehari-hari, dan kurang suka teori abstrak. Gaya belajar visual berarti belajar dengan bantuan bagan, skema, dan diagram alir dari rangkaian teori yang sedang mereka kupas. Keempat gaya belajar ini selaras dengan kecenderungan generasi digital yang kehidupannya sarat dengan interaksi lewat berbagai media virtual seperti ponsel dan internet. Gaya hidup generasi $\mathrm{X}$ dan $\mathrm{Y}$

\footnotetext{
${ }^{11}$ Trilling, B \& Fadel, C. (2009). 21st-century skills: learning for life in our times. US: Jossey-Bass A Wiley Imprint.

${ }^{12}$ Tapscott, Don, 2013. Grown Up Digital. Jakarta: Gramedia Pustaka Utama. \& Wibawanto, Hari. 2018. Generasi Z dan Pembelajaran di Pendidikan Tinggi. https://event.elearing.itb.ac.id. (diunduh 25 Juni 2021).

${ }^{13}$ Retnaningdyastuti, M. T. S. R. (2018). Tantangan dan peluang siswa dan guru BK di era disrupsi. Prosiding, 6. Hlm. 8.
} 
berhadapan dengan isu workaholic, gaya hidup anak-anak generasi $\mathrm{Z}$ nantinya akan diwarnai dengan sikap speedaholic (segala-galanya diukur dengan kecepatan, siapa cepat dia dapat) dan winaholic (berlomba-lomba mengalahkan lawan) dan persaingan memburu karier. Perilaku belajar generasi $\mathrm{Z}$ adalah sikap minimalis, pragmatis, dan ketergantungan pada google atau yahoo setiap kali menghadapi tugas dan masalah. ${ }^{14}$

\section{Tantangan dan Peluang bagi Siswa di Era Disrupsi}

Menurut Kemenristekdikti ada beberapa kecakapan yang harus dimiliki siswa agar dapat menyesuaikan diri dengan perkembangan ilmu dan teknologi di era disrupsi sebagai berikut :

- Keterampilan belajar dan inovasi. Berpikir kritis dan pemecahan masalah dalam komunikasi dan kreativitas kolaboratif dan inovatif.

- Keahlian literasi digital. Literasi media baru dan literasi ICT

- Kecakapan hidup dan karir. Memiliki kemampuan inisiatif yang fleksibel dan inisiatif adaptif, dan kecakapan diri secara sosial dalam interaksi antarbudaya, kecakapan kepemimpinan produktif dan akuntabel, serta bertanggungjawab.

Walaupun mudah menggunakan ICT, untuk menguasai kecakapan-kecakapan diatas tetap membutuhkan proses, daya juang dan daya tahan. Selain itu juga perlu diatasi kendalakendalanya antara lain: gaya hidup mereka (sikap speedaholic dan winaholic) serta perilaku belajar (sikap minimalis, pragmatis, dan ketergantungan pada internet setiap kali menghadapi tugas dan masalah). ${ }^{15}$

Masih perlu ditingkatkan kesadaran siswa terhadap Digital Citizenship yakni norma penggunaan teknologi secara benar dan bertanggung jawab. Hilangnya banyak pekerjaan karena berubah menjadi otomatisasi, menjadi tantangan bagi siswa untuk menciptakan lapangan pekerjaan baru. Peluang bagi siswa agar mampu memenuhi tuntutan kehidupan di era disrupsi antara lain sebagai berikut: kondisi siswa sebagai native digital memudahkan mengimplementasikan kegiatan belajar dengan pendekatan hybrid learning dan multitasking, suasana demokratis yang diciptakan bersama guru BK memungkinkan bagi siswa untuk berinisiatif dan berkreasi, sikap kemitraan guru membuat kenyamanan bagi siswa untuk mencoba berinovasi, adanya kebijakan Ujian Nasional Online mendukung ketersediaan perangkat ICT. ${ }^{16}$

\section{Karakteristik Guru BK di Era Disrupsi}

Guru BK adalah digital immigrant, karena kemampuan menggunakan ICT dampak dari studi lanjut atau bekerja. Perubahan karakter masyarakat secara fundamental sebagaimana terjadi pada era disrupsi pada abad 21 tentu berimplikasi terhadap karakteristik guru termasuk guru BK. Jika masyarakat pada era disrupsi ini berubah ke masyarakat digital, maka guru BK juga perlu segera mentransformasikan diri, baik secara teknik maupun sosiokultural. ${ }^{17}$

${ }^{14}$ Susana, Tjipto. 2012. Kesetiaan pada Panggilan di Era Digital. Orientasi Baru. Vol. 21. No. 1. Hlm. 69.

${ }^{15}$ Susana, Tjipto. 2012. Kesetiaan pada Panggilan di Era Digital. Orientasi Baru. Vol. 21. No. 1. Hlm. 58.

${ }^{16}$ Anggraeni, Anastasia D. 2017. The Roleof School Counselors in Forming Student Becoming a Digital Citizen. Jurnal Bimbingan dan Konseling Teraputik. Vol. 1. No. 2. Hal. 151 \& Kasali, Rhenald. 2017. Meluruskan Pemahaman Soal Disruption. https://kompas.com 5 Mei 2017 (Diunduh 25 Juni 2021).

${ }^{17}$ Kemenristekdikti. 2018. Modul Kompetensi Pedagogik Pendidikan Profesi Guru dalam Jabatan Tahun 2018. Jakarta: Kemenristekdikti. \& Mardina, Riana. 2011. Potensi Digital Natives dalam 
Menurut Kemenristekdikti karakteristik guru BK yang mampu mentransformasikan diri di era disrupsi sebagai berikut: (a) meningkatkan minat baca dan menambah koleksi buku; (b) mampu menjadi fasilitator, motivator dan inspirator; (c) mengunggah karya-karya tulisnya yang berkontribusi bagi upaya peningkatan kualitas layanan bimbingan dan konseling; (d) menerapkan pola hybrid learning (kombinasi tatap muka dan online) dan multitasking secara kreatif dan inovatif untuk meningkatkan kualitas layanan bimbingan dan konseling; dan (e) menerapkan pendekatan konstruktivistik berbasis ICT. ${ }^{18}$

Menurut pendapat Alaydrus karakteristik guru BK di era disrupsi sebagai berikut :

* Life-long learner. Pembelajar seumur hidup. Guru BK perlu mengupgrade terus pengetahuannya dengan banyak membaca serta berdiskusi dengan pengajar lain atau bertanya pada para ahli. Tak pernah ada kata puas dengan pengetahuan yang ada, karena zaman terus berubah dan guru BK wajib up to date agar dapat mendampingi siswa berdasarkan kebutuhan mereka.

* Kreatif dan inovatif. Siswa yang kreatif lahir dari guru BK yang kreatif dan inovatif. Guru diharap mampu memanfaatkan variasi sumber belajar untuk menyusun kegiatan baik di dalam kelas maupun di luar kelas.

* Mengoptimalkan teknologi. Dengan cara blended learning, gabungan antara metode tatap muka tradisional dan penggunaan digital dan online media.

- Reflektif. Guru BK yang reflektif adalah guru BK yang mampu menggunakan penilaian proses dan hasil layanan untuk meningkatkan kualitas layanan bimbingan dan konseling.

* Kolaboratif. Guru BK dapat berkolaborasi dengan siswa dalam layanan bimbingan dan konseling. Selalu ada mutual respect dan kehangatan sehingga layanan bimbingan dan konseling berlangsung lebih menyenangkan. Selain itu guru BK juga membangun kolaborasi dengan orang tua melalui komunikasi aktif dalam memantau perkembangan anak.

* Menerapkan student centered. Dalam hal ini, siswa memiliki peran aktif dalam pembelajaran sehingga guru hanya bertindak sebagai fasilitator.

- Menerapkan pendekatan diferensiasi. Dalam menerapkan pendekatan ini, guru BK mendesain layanan bimbingan dan konseling berdasarkan gaya belajar peserta didik (siswa), pengelompokkan siswa berdasarkan minat, kemampuan dan permasalahannya. Dalam melakukan penilaian guru BK menerapkan assessment alternative. ${ }^{19}$

\section{Peranan Teknologi dalam Bimbingan Dan Konseling}

Teknologi informasi telah menjadi fasilitas bagi kegiatan berbagai sektor kehidupan, dan telah menyentuh layanan bimbingan dan konseling. Teknologi informasi dalam layanan bimbingan dan konseling masuk kepada dukungan sistem bimbingan dan konseling sebagai suatu proses pemberian bantuan kepada individu (konseli), dilaksanakan melalui berbagai macam layanan. Layanan tersebut saat ini, pada saat jaman semakin berkembang, tidak hanya dapat dilakukan dengan tatap muka secara langsung, tapi juga bisa dengan memanfaatkan media atau teknologi informasi yang ada. Tujuannya adalah tetap memberikan bimbingan dan

Representasi Literasi Informasi Multimedia Berbasis Web di Perguruan Tinggi. Jurnal Pustakawan Indonesia, Vol.11, No.1. Hlm. 7.

${ }^{18}$ Kemenristekdikti. 2018. Modul Kompetensi Pedagogik Pendidikan Profesi Guru dalam Jabatan Tahun 2018. Jakarta: Kemenristekdikti.

${ }^{19}$ Alaydrus, Ragwan. 2017. Tujuh Karakteristik Guru Abad 21. https://pendidikkreatif. wordpress.com (diunduh 25 Juni 2021). 
konseling dengan cara-cara yang lebih menarik, interaktif, dan tidak terbatas tempat, tetapi juga tetap memperhatikan azas-azas dan kode etik dalam bimbingan dan konseling. ${ }^{20}$

Penggunaan teknologi informasi, khususnya internet dalam layanan bimbingan dan konseling adalah dengan sebutan e-counseling. Melalui layanan ini dirasa cukup efektif dan efisien dalam proses konseling jarak jauh yang dilakukan oleh konselor dan klien untuk membantu masalah-masalah yang dihadapi klien. Para konseli juga perlu diberikan suatu sosialisasi agar kemajuan teknologi informasi tersebut bisa dimanfaatkan sesuai apa yang diharapkan. Dengan kata lain, teknologi informasi tersebut tidak disalahgunakan untuk hal yang negatif. Jika konselor dan konseli sudah paham akan manfaat dan pentingnya teknologi informasi dalam menunjang proses layanan bimbingan dan konseling, maka ke depannya bimbingan dan konseling akan menjadi suatu bidang pendidikan yang inovatif dan efisien berkat kemajuan teknologi informasi namun tetap tidak menghilangkan esensi dari layanan bimbingan dan konseling itu sendiri. ${ }^{21}$

Menurut Moh. Surya mengemukakan bahwa sejalan dengan perkembangan teknologi komputer, interaksi antara konselor dengan klien tidak hanya dilakukan melalui hubungan tatap muka tetapi dapat juga dilakukan melalui hubungan secara virtual (maya) melalui internet dalam bentuk "cyber counseling". Layanan bimbingan dan konseling ini merupakan salah satu model pelayanan konseling yang inovatif dalam upaya menunjukkan pelayanan yang praktis dan bisa dilakukan dimana saja asalkan ada koneksi atau terhubung dengan internet. Peranan bimbingan dan konseling mengacu pada perkembangan serta kemajuan teknologi yang mutakhir, salah satunya ialah penggunaan alat atau media komunikasi serta informasi elektronik baik secara online maupun offline. Penggunaan media teknologi yang mutakhir akan senantiasa merubah gaya serta penerapan bimbingan dan konseling yang konvensional. Sebagaimana tujuan dari kemajuan teknologi yaitu untuk mengefisienkan atau mempermudah akses informasi, maka penerapannya dalam bimbingan dan konseling juga mengacu pada cara yang sama tanpa mengubah konteks dari bimbingan dan konseling tersebut. Alat-alat atau media dalam akses informasi di era global ini sangat beragam dan mutakhir, seperti telepon selular, komputer, internet dan media lainnya yang langsung atau online ataupun yang tidak langsung atau offline. Maka semua media teknologi informasi tersebut akan mempermudah akses pemberian bantuan terhadap individu jika dimanfaatkan secara tepat guna dan terlatih. ${ }^{22}$

Menurut Yoezron, teknologi informasi memiliki beberapa fungsi dan peranan dalam bimbingan konseling yaitu: Pertama Publikasi, teknologi informasi dimanfaatkan sebagai sarana pengenalan kepada masyarakat luas dan juga sebagai pemberi informasi mengenai bimbingan dan konseling (BK). Kedua Pelayanan dan bantuan, dalam fungsi ini bimbingan dan konseling dilakukan secara tidak langsung dengan bantuan teknologi informasi. Ketiga

${ }^{20}$ Kusumawati, E. (2020). PELUANG DAN TANTANGAN LAYANAN BIMBINGAN DAN KONSELING DI ERA DISRUPSI. Counsenesia Indonesian Journal Of Guidance and Counseling, 1(02), hlm. 68.

${ }^{21}$ Nurihsan, Ahmad Juntika. 2007. Strategi Layanan Bimbingan\&Konseling. Bandung: Refika Aditama.

${ }^{22}$ Tresna, I Gede. 2014. Teknologi Informasi dalam BK. Tersedia di: http://tresnainnovation. blogspot.com. [25 Juni 2021]. 
Pendidikan, dikatakan demikian karena didalam informasi yang diberikan melalui sarana TI ini mengandung unsur pedidikannya. ${ }^{23}$

Banyak sekali manfaat yang dapat diperoleh dari teknologi komputer dalam menunjang profesionalitas kerja konselor, maka konselor perlu mengetahui potensi apa yang terkandung pada teknologi komputer. Sesuai dengan kompetensi akademik konselor disebutkan bahwa seorang konselor professional harus menguasai khasanah teoritik dan prosedural termasuk teknologi dalam bimbingan dan konseling. Walaupun kegiatan konseling dilakukan dengan jarak jauh namun kerahasian konseli harus tetap terjaga. Media layanan dapat menggunakan telepon, telekonferensi, dan internet. Layanan bimbingan dan konseling tidak selalu face to face atau tatap muka. Terdapat layanan yang lebih mudah yaitu dengan cyber counseling yang memungkinkan konseli tidak merasa malu canggung yang bisa dilakukan kapan dan dimana saja. Memanfaatkan teknologi informasi dizaman modern ini menjadi sangat relevan ketika diterapkan dalam kegiatan bimbingan dan konseling. Oleh karena itu, hal ini diharapkan menjadi efektif untuk membantu individu dalam perkembangannya secara optimal dan menyesuaikan dengan kemajuan zaman tanpa tergerus oleh pengaruh negatif dari kemajuan tersebut. $^{24}$

\section{Kelebihan atau Keuntungan Penggunaan Teknologi Informasi dalam Bimbingan dan Konseling.}

Menurut Zamroni keuntungan dari guru BK menyelenggarakan BK dengan bantuan teknologi, konselor memiliki kemampuan untuk menggunakan sumber teknologi lain yang dapat dimanfaatkan dalam bimbingan konseling. Hal ini dapat meningkatkan kemampuan diri dan konselor itu sendiri serta membangun prestise dikalangan guru lain disekolah. Lebih lanjut kelebihan/keuntungan pelayanan bimbingan dan konseling melalui teknologi informasi, diantaranya sebagai berikut :

* Pelayanan melalui teknologi informasi mudah di akses.

* Tidak membutuhkan biaya transportasi.

* Mengurangi kesulitan jadwal yang berkaitan dengan program kelompok.

* Pelayanan melalui teknologi informasi bersifat semi anonym.

* Klien lebih mau terbuka berbicara tentang masalahnya karena ia tidak berkomunikasi secara face to face, sehingga ia dapat lebih siap dan terbuka.

* Pelayanan melalui teknologi informasi dan komunikasi berbasis individu.

* Konselor dapat menyesuaikan kesiapan siswa (klien) dalam mengambil tindakan yang diperlukan, memotivasi diri, dan meningkatkan keterampilan kliennya.

- Pelayanan melalui teknologi informasi dan komunikasi formatnya harus memfasilitasi konseling yang proaktif.

* Setelah siswa (klien) membuka komunikasi via teknologi informasi awal, maka konselor berinisiatif untuk memulai suatu kontak berikutnya sehingga ia dapat menciptakan suatu

${ }^{23}$ Rahmani, Yoezron Isman. 2010. Urgensi Teknologi Informasi dalam Bimbingan dan Konseling. [Online]. Tersedia di: http://yoezronbloon.blogspot.com [25 Juni 2021].

${ }^{24}$ Kusumawati, E. (2020). PELUANG DAN TANTANGAN LAYANAN BIMBINGAN DAN KONSELING DI ERA DISRUPSI. Counsenesia Indonesian Journal Of Guidance and Counseling, 1(02), hlm. 69. 
taraf terapis berupa dukungan sosial dan siswa (klien) bertanggung jawab selama proses penyembuhannya.

- Pelayanan melalui teknologi informasi formatnya menggunakan ijin protokol yang terstruktur. Hal ini dapat memberikan konselor suatu kerangka kerja tertulis yang dapat memastikan pemenuhan topik penting ketika bekerja khusus kepada masing-masing individu pada setiap sesi, sehingga menghasilkan suatu intervesi yang ringkas, terpusat, dan sesuai dengan pribadi klien. ${ }^{25}$

\section{PENUTUP}

Era disrupsi adalah istilah lain dari industri 4.0. Disebut era disrupsi karena otomatisasi dan konektivitas di sebuah bidang akan membuat pergerakan dunia menjadi tidak linier. Salah satu karakteristik unik dari industri 4.0 adalah pengaplikasian kecerdasan buatan atau artificial intelligence. Salah satu bentuk pengaplikasian tersebut adalah penggunaan robot untuk menggantikan tenaga manusia sehingga lebih murah, efektif, dan efisien. Era disrupsi adalah era revolusi industri 4.0 yang ditandai perubahan fundamental dalam kehidupan yang lebih efisien dan bermanfaat di masyarakat sebagai dampak dari inovasi teknologi digital melalui penguasaan dan pemanfaatan ilmu pengetahuan dan teknologi untuk meningkatkan kualitas hidup. Menurut Mannheim generasi adalah kelompok yang terdiri dari individu yang memiliki kesamaan dalam rentang usia dan mengalami peristiwa sejarah penting dalam suatu periode waktu yang sama. Tapscott (2013: 18-39) dalam bukunya dengan judul "Grown Up Digital" membagi demografi penduduk Amerika kedalam beberapa kelompok generasi sebagai berikut : (1) The Baby Boom (lahir antara 1946-1964), (2) The Baby Bust atau Generasi X (lahir antara 1965-1976), (3) The Millennial atau Generasi Y (lahir antara 19771997) dan (4) Generation Net atau Generasi Z (lahir antara 1998 hingga kini).

Menurut Kemenristekdikti ada beberapa kecakapan yang harus dimiliki siswa agar dapat menyesuaikan diri dengan perkembangan ilmu dan teknologi di era disrupsi sebagai berikut : (1) Keterampilan belajar dan inovasi. Berpikir kritis dan pemecahan masalah dalam komunikasi dan kreativitas kolaboratif dan inovatif. (2) Keahlian literasi digital. Literasi media baru dan literasi ICT. (3) Kecakapan hidup dan karir. Memiliki kemampuan inisiatif yang fleksibel dan inisiatif adaptif, dan kecakapan diri secara sosial dalam interaksi antarbudaya, kecakapan kepemimpinan produktif dan akun tabel, serta bertanggungjawab. Guru BK adalah digital immigrant, karena kemampuan menggunakan ICT dampak dari studi lanjut atau bekerja. Perubahan karakter masyarakat secara fundamental sebagaimana terjadi pada era disrupsi pada abad 21 tentu berimplikasi terhadap karakteristik guru termasuk guru BK. Jika masyarakat pada era disrupsi ini berubah ke masyarakat digital, maka guru BK juga perlu segera mentransformasikan diri, baik secara teknik maupun sosiokultural.

Menurut Yoezron, teknologi informasi memiliki beberapa fungsi dan peranan dalam bimbingan konseling yaitu: Pertama Publikasi, teknologi informasi dimanfaatkan sebagai sarana pengenalan kepada masyarakat luas dan juga sebagai pemberi informasi mengenai

25 Zamroni. 2002. Pemanfaatan Teknologi Informasi (TI) Dalam Layanan Bimbingan dan Konseling

Sebagai Representasi Berkembangnya Budaya Profesional Konselor dalam Melayani Siswa. E-journal Bimbingan Konseling, 2(1). 
bimbingan dan konseling (BK). Kedua Pelayanan dan bantuan, dalam fungsi ini bimbingan dan konseling dilakukan secara tidak langsung dengan bantuan teknologi informasi. Ketiga Pendidikan, dikatakan demikian karena didalam informasi yang diberikan melalui sarana TI ini mengandung unsur pedidikannya. Menurut Zamroni keuntungan dari guru BK menyelenggarakan BK dengan bantuan teknologi, konselor memiliki kemampuan untuk menggunakan sumber teknologi lain yang dapat dimanfaatkan dalam bimbingan konseling. Hal ini dapat meningkatkan kemampuan diri dan konselor itu sendiri serta membangun prestise dikalangan guru lain disekolah.

\section{DAFTAR PUSTAKA}

Sainuddin, Ibnu Hajar. "Dakwah di Era Sosial Media".

Retnaningdyastuti, M. T. S. R. (2018). Tantangan dan peluang siswa dan guru BK di era disrupsi. Prosiding.

Nurpitasari, E., Aji, B. S., \& Kurniawan, S. J. (2018, November). Pengembangan Kompetensi Teknologi dan Peran Konselor dalam Menghadapi Peserta Didik di Era Disrupsi. In Seminar Nasional Bimbingan Konseling (Vol. 2, No. 1, pp. 10-14).

Kusumawati, E. (2020). PELUANG DAN TANTANGAN LAYANAN BIMBINGAN DAN KONSELING DI ERA DISRUPSI. Counsenesia Indonesian Journal Of Guidance and Counseling, 1(02).

Fatmawati, Nur Ika. "Literasi Digital, mendidik anak di era digital bagi orang tua milenial." Madani Jurnal Politik Dan Sosial Kemasyarakatan 11.2 (2019), hlm.120.

Setiawan, Rizki. "Kebebasan Ekspresi Individual dalam Pembangunan Manusia Era Digital." Prosiding Seminar Nasional Pendidikan FKIP. Vol. 1. No. 2. 2017, hlm. 169.

Tjandrawina, R.R. (2016). Industri 4.0: Revolusi industri abad ini dan pengaruhnya pada bidang kesehatan dan bioteknologi. Jurnal Medicinus, Vol 29 No 1, Edisi April.

Trilling, B \& Fadel, C. (2009). 21st-century skills: learning for life in our times. US: JosseyBass A Wiley Imprint.

Tapscott, Don, 2013. Grown Up Digital. Jakarta: Gramedia Pustaka Utama. \& Wibawanto, Hari. 2018. Generasi Z dan Pembelajaran di Pendidikan Tinggi. https://event.elearing.itb.ac.id. (diunduh 25 Juni 2021).

Susana, Tjipto. 2012. Kesetiaan pada Panggilan di Era Digital. Orientasi Baru. Vol. 21. No. 1. Hlm. 69.

Anggraeni, Anastasia D. 2017. The Roleof School Counselors in Forming Student Becoming a Digital Citizen. Jurnal Bimbingan dan Konseling Teraputik. Vol. 1. No. 2. Hal. 151

Kasali, Rhenald. 2017. Meluruskan Pemahaman Soal Disruption. https://kompas.com 5 Mei 2017 (Diunduh 25 Juni 2021). 
Kemenristekdikti. 2018. Modul Kompetensi Pedagogik Pendidikan Profesi Guru dalam Jabatan Tahun 2018. Jakarta: Kemenristekdikti.

Alaydrus, Ragwan. 2017. Tujuh Karakteristik Guru Abad 21. https://pendidikkreatif. wordpress.com (diunduh 25 Juni 2021).

Nurihsan, Ahmad Juntika. 2007. Strategi Layanan Bimbingan\&Konseling. Bandung: Refika Aditama.

Tresna, I Gede. 2014. Teknologi Informasi dalam BK. Tersedia di: http://tresnainnovation. blogspot.com. [25 Juni 2021].

Rahmani, Yoezron Isman. 2010. Urgensi Teknologi Informasi dalam Bimbingan dan Konseling. [Online]. Tersedia di: http://yoezronbloon.blogspot.com [25 Juni 2021].

Zamroni. 2002. Pemanfaatan Teknologi Informasi (TI) Dalam Layanan Bimbingan dan Konseling Sebagai Representasi Berkembangnya Budaya Profesional Konselor dalam Melayani Siswa. E-journal Bimbingan Konseling, 2(1). 